\title{
Factors Affecting Consumers' Purchase Decision of Over-The-Counter (OTC) Medicines: Empirical Evidences from Community Pharmacies in Ethiopia
}

\author{
Meseret Wube Temechewu \\ Department of Marketing Management, Addis Ababa University, Addis Ababa, Ethiopia \\ Mulugeta Gebremedhin (PhD) \\ Department of Marketing Management, Addis Ababa University, Addis Ababa, Ethiopia
}

\begin{abstract}
Purpose: the aim of this study was to examine factors affecting consumers' purchase decision of over-thecounter (OTC) medicines from community pharmacies in Ethiopia.

Design/methodology/approach: A quantitative research design was used to test the effect of various factors on consumer purchase decision of OTC medicines. Descriptive and explanatory research approaches were used to describe and investigate the relationship between dependent and independent variables. Both primary and secondary data were collected using self-administered questionnaire and Statistical Package for the Social Sciences (SPSS) version 23 was used to analyze the data.

Findings: the researchers found that, pharmacist's recommendation, price, and country of origin of OTC medicines have positive and significant effect on consumers' purchase decision of OTC medicines. Even though, previous experience and families' and friends' recommendation have positive effect on consumers' purchase decision of OTC medicines, is not statistically significant.

Originality/value: Few studies have been conducted on OTC medicines from pharmacy practice perspective and their result showed that there are significant numbers of consumers using OTC medicines. In the best of authors' knowledge, however; no research has been conducted on OTC medicines from consumer behavior perspectives, especially, purchase decision in Ethiopia.
\end{abstract}

Keywords: Community Pharmacy, OTC Medicine, and Purchase Decision

DOI: $10.7176 / \mathrm{JMPB} / 65-02$

Publication date: April $30^{\text {th }} 2020$

\section{Introduction}

The use of non-prescription medicines is the most prevalent form of medical care in the world (Covington, 2002), and it have seen greater sales growth than that of prescription medicines since 2008 (Tisman, 2015).

OTC medicine market is expected to continue expanding in the near future for several reasons. Firstly, selfmedication is growing and OTC medicines provide a convenient and inexpensive way to treat minor and ordinary health problems. Secondly, prescription only-to-OTC switching is not likely to abate, making more medications available without a prescription. Thirdly, health literacy is likely to increase, especially as use of the internet as a source of self-medication information expands (Denise, et al., 2010).

In addition, Battistoni et al., (2014) suggested that OTC medicine market has two very peculiar characteristics; which are, very importantly, consumers buy products in response to their specific health needs; nonetheless, the market is not strictly regulated in the same way that the prescription market, which allows firms to choose their pricing and communication strategies. On the other hand, consumers are not forced by physicians to buy one specific drug, so they can choose the one they prefer by themselves.

Recently, the practice of OTC medicine consumption is widely accepted and successfully integrated into many health care systems throughout the world (WHO, 2000). In most economically deprived countries including Ethiopia, many drugs are dispensed OTC and majority of health related problems, nearly $60-80 \%$, are treated through self-medication as lower cost alternative and if it is used appropriately, use of OTC medicine could lighten the demand on doctors and make people more health conscious (DACA and MSH/ SPS, 2009).

According to FMoH \& WHO (2003), the pharmaceutical industry has always been of interest to marketers as a large and internationally competitive industry. Therefore, understanding consumers' behavior before they made purchase decision will help for product manufacturers and service providers to develop strategies in line with customers' actions. Particularly knowing what makes customers to prefer between brands will make the manufacturer to adapt strategies based on the influential factors (Kotler and Armstrong, 2012).

The private pharmaceutical market is supplied majorly by the products, which are being imported from different companies from different continents (Andualem, 1995). Though compiled data on most of the pharmaceutical economics are rare, it can, however, be said that the country doesn't have a developed pharmaceutical industry, but only few and small factories which mainly manufacture generic products using a 
commissioned master formula developed elsewhere. These factories produce some $25-30 \%$ of the essential drugs that the health sector of the country needs. The remaining $70-75 \%$ of the country's medicines market has been left vacant for imported products (FMoH \& WHO, 2003).

Bond (n.d.) also explained in most of the world, access to and supply of medicines is governed by a regulatory framework that is based on perceptions of the risks and benefits of the medicine to the population. Accordingly, there are two broad categories of medicines in Ethiopia: Prescription only medicines (POM); medicines only available to the public when prescribed by an authorized medical practitioner such as medical doctors, nurses, health officers, and dental doctors, and Non- prescription or Over- the- counter (OTC) medicines; medicines that can be sold directly to a consumer without a prescription from pharmacy personnel.

Currently there are more than 24 therapeutic categories of OTC medicines and within these categories; there are more than 92 types of OTC medicine in national drug list of Ethiopia (FMHACA, 2012).

\section{Research Objectives}

The general objective of this study was to investigate factors affecting consumers purchase decision of over-thecounter (OTC) medicine from community pharmacies in Ethiopia and specific objectives were;

$\checkmark$ To examine the effect of pharmacist's recommendation on consumer purchase decision of OTC medicines.

$\checkmark \quad$ To determine the effect of family's and friends' recommendation on consumer purchase decision of OTC medicines.

$\checkmark$ To identify the effect of country of origin on consumer purchase decision of OTC medicines.

$\checkmark$ To analyze the effect of previous experience on purchase decision of OTC medicines.

$\checkmark$ To identify the effect of price on purchase decision of OTC medicines.

\section{Scope of the Study}

This study has three main scopes.

Geographically, this study is limited to Addis Ababa, which is a small portion of the country; this is due to cost and difficulty to maintain large number of population throughout Ethiopia. Therefore, the findings might not be the reflection of consumer purchase decision of the whole of the country.

Conceptually, first it is limited to OTC medicines. This is because OTC medicines are representing one of the main product categories in pharmacies and that are available to the consumers without prescription, and the consumers have the possibility to make their product choice independent of physicians. On the other hand, because of limited resources and for a focused result, the researcher decided to consider pharmacist recommendation, families' and friends' recommendation, past experience, country of origin and the price of OTC medicine only as independent variables, though there are other factors which may affect consumers purchase decision of OTC medicines. These are; packaging, advertisement, brand name, dosage, symptom, and medical examination price. This is mainly because; (1) according to Donohue et al., (2007) direct to consumer advertising (DTCA) of prescription medicines was introduced to USA and other developed countries in early1990s. However, in Ethiopia, DTCA is not started yet due to the regulation of pharmaceutical promotion, companies are prohibited from promotional efforts directed to public (FMHACA, 2012). (2) Medical examination price will be a determinant factor for the consumers to select their treatment option visiting either a doctor or self-medication (going to pharmacy). Therefore, it is not considered as determinant factor for their purchase decision of OTC medications.

Methodologically, this study targeted only on community pharmacies as population, and did not include hospital pharmacies. This is because, community pharmacists are most accessible to the public, an opportunity to become more than medication dispensers. Unlike community pharmacies, the businesses of the hospital pharmacies are depending on prescription only medicines from respective hospital where they are in (Melton and Lai, 2017).

\section{Literature Review}

Several studies have been conducted in different countries of Europe and Asia to examine factors affecting consumers purchase decision of OTC medicines. As the researchers' noted, few studies have been conducted on OTC medicines from pharmacy practice perspective (Girma, et al., 2011), (Abdissa \& Anbessa, 2015), (Mohammed, 2017), and (Tewodros, et al., 2015). However, in the best of authors' knowledge, no research has been conducted on OTC medicines from consumer behavior perspectives, especially, purchase decision in Ethiopia.

Therefore, this study will provide an insight to pharmaceuticals marketers on factors which affect consumer purchase decision of OTC medicines. In addition, based on the finding, pharmaceutical marketers will design their marketing strategies, in efficient and effective manner to have sustainable competitive advantages. Moreover, the result will have paramount importance for being as a baseline for further study. 


\section{Consumer Purchase Decision Process}

Consumers generally go through a five-stage of decision-making process whenever they make a purchase. The model implies that customers pass through all of the stages in every purchase. However, in more routine purchases, customers frequently omit or reverse some of the stages (Furaiji et al., 2012) and (Solomon, et al., 2006).

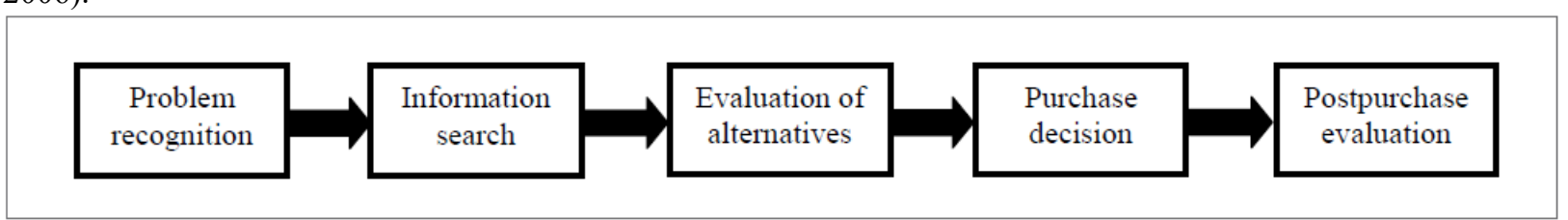

Figure 1: Purchase Decision Process (Source: Furaiji et.al. 2012, p.80)

Problem Recognition: it occurs when the consumer perceives a need and becomes motivated to solve the problem. At this stage, the buyer recognizes a problem or need or responds to a marketing stimulus. Next, the consumer needs to decide how much information (if any) is required to make the decision. (Belch and Belch, 2003).

Information Search: According to Kotler and Armstrong (2012), once consumers perceive a problem or need that can be satisfied by the purchase of a product or service, they begin to search for information needed to make a purchase decision.

Alternative Evaluation: the consumer compares the various brands or products and services s/he has identified as being capable of solving the consumption problem and satisfying the needs or motives that initiated the decision process. An important determinant of the extent of the evaluation is whether the customer feels "involved" in the product. (Pride \& Ferrell, 2007).

Purchase Decision: At some point in the buying process, the consumer must stop searching for and evaluating information about alternative brands in the evoked set and makes a purchase decision. As an outcome of the alternative evaluation stage, the consumer may develop a purchase intention or predisposition to buy a certain brand. Purchase intentions are generally based on a matching of purchase motives with attributes or characteristics of brands under consideration (Belch and Belch, 2003).

Post-purchase Evaluation: the consumer decision process does not end with the purchase. After using the product or service, the consumer compares the level of performance with expectations and is either satisfied or dissatisfied. Satisfaction occurs when the consumer's expectations are either met or exceeded; dissatisfaction results when performance is below expectations. The post-purchase evaluation process is important because the feedback acquired from actual use of a product will influence the likelihood of future purchases (Solomon, et al., 2006).

Accordingly, before deciding to buy specific brand of over-the-counter medicine, consumers will go through several stages such as the introduction of a problem or a symptom of disease, then find the appropriate information on drug indications, and evaluate alternatives to these drugs on the market, and finally decided that the right medication that will be used. When consumers search for information about the drug, some consumers will be interested to find out as much and are very concerned about several types and brands of drugs for the same indication. For other consumers who demand the same drug the situation was not same. This is related to the involvement of consumers where the consumers who perceive that a product is said to be more important personally involved (Kotler and Keller, 2012). After buying the drug, consumers will evaluate whether to recover unreachable expectations of the drug chosen and realized in the form of feeling satisfied or not satisfied (Kotler et al., 2005).

\section{Factors Affecting Consumer Purchase Decision of OTC Medicines}

Based on related literatures, the researchers identified five factors that mainly affect consumers' purchase decision of Over- the-counter medicines. These are; pharmacist' recommendation, families' and friends' recommendation, past experience, country of origin and the price of OTC medicine.

\section{i. Pharmacist's Recommendation}

According to Villako, et al. (2012), the role of the pharmacist in giving advice concerning OTC medicines and this includes assisting in selecting OTC products' dosages and forms that are safe and effective for achieving specific health outcomes (Kotecki, 2002). Major and Vincze (2010) suggested that the pharmacist becomes the gatekeeper who is responsible for recommending the appropriate health care resources to each patient. Other scholars, Wieringa, et al., (2015) added on the role of pharmacists with respect to OTC medicines is that many patients seeking an OTC solution to their health problems may prefer to receive guidance from a health-care provider (i.e. pharmacist) to reduce their perceived post-purchase risk.

ii. Families' and Friends' Recommendation

According to Takhire and Joorshari (2015), word-of-mouth (WOM) is described as costumers' interpersonal 
communication about products or services, and it plays a key role in influencing consumer attitudes, tendencies and behaviors. In addition, they suggested that WOM has major impact on consumer choice and post purchase perceptions. The information about the brand has been used by the other group members also affect the decision to skip the existing brand and to move on to the purchase those brand that is using by other group members. Cîrstea, et al. (2017) also believed that the purchase decision is influenced by two important factors medical or pharmacist advice and the perceived value of information, which can be from reference groups; primarily people who have purchased / used that drug, as well as colleagues, friends or family.

\section{iii. Country of Origin}

According to Saydan (2013), country-of-origin is one of the most important factors that significantly influence the purchasing decision of consumers. the country of origin "made in label" has been used as an important function in meeting with today's competitive and global environment in order to increase product sales. Laroche et al., (2005) also revealed that a product's country of origin influences consumers' evaluation of it. In addition, Pappu et al. (2006) in their study suggested that country of origin of a product is an important marketing element known to influence consumer behavior.

Finally, familiarity with the name or brand has also been reported in pharmacy is an important factor influencing purchases of OTC medicines. This is because medicine's country of origin, which was associated with the manufacturing company's background, as well as by the manufacturing company have valuated higher than the product's advertisement and packaging (Kevrekidis, et al., 2018).

\section{iv. Previous Experience}

Because the effect of a drug on health conditions can be learned only through use, prior experience with and knowledge about the product play significant roles in purchase decisions. Due to the difficulty to obtain such information about the drug's quality, patients are quite reluctant to switch once they have found a drug that works for them (Wieringa, et al., 2015).

Consumers' purchasing experience involves the internal and external memory which would play an important role in the purchasing process (Bettman, 1979). Internal memory comes from the actual experience consumers have with the goods or service while external memory is originated from information related to the goods or service. The experience of purchasing last longer and will remain in consumers' mindset. Therefore, they will immediately start evaluating on the items they purchased and the result of the purchasing experience toward the items will be kept in their mindset for a very long time (Keller, 2001).

According to Shohel, et al. (2013), direct experience with the product, price range and brand reliance are important determinants of repetitive purchase behavior on OTC drugs. Dadhich \& Dixit (2017) also reflected that familiarity with the OTC brand is the key factor in determining the repetitive purchase of OTC product.

Lastly, decision-making could originate from consumers' existing knowledge or experience. The emphasis on previous experience was supported by the reported tendency of the participants to often pick a specific product from a certain category of medicines, which implies that they are loyal and long-term user of certain medicines (Kevrekidis, et al., 2018).

\section{v. Price}

Consumers are sensitive to the prices because they want to get maximum benefits of using their money and time. That means, consumers are very rational to judge what they are getting from buying a product or service in exchange of their payments for it (Mamun, et al., 2014). Other scholars, Gogoi (2013), and Kevrekidis, et al. (2018) also described that customers always think that purchase with a low cost, simple packaging and littleknown product is a high risk since the quality of these products is not trustable.

Likewise, Asamoah and Chovancova (2011) suggested that consumers are price takers and accept prices at face value or as given by the producers. Marketers acknowledge that consumers are vigorously assess price information, decoding prices in terms of their knowledge from previous purchasing experience, formal communications (advertising and sales promotions), informal communications (friends, colleagues, or family members), and point-of-purchase or online resources.

\section{Conceptual Model}

Based on the above related literatures and concepts the following conceptual framework was developed. 


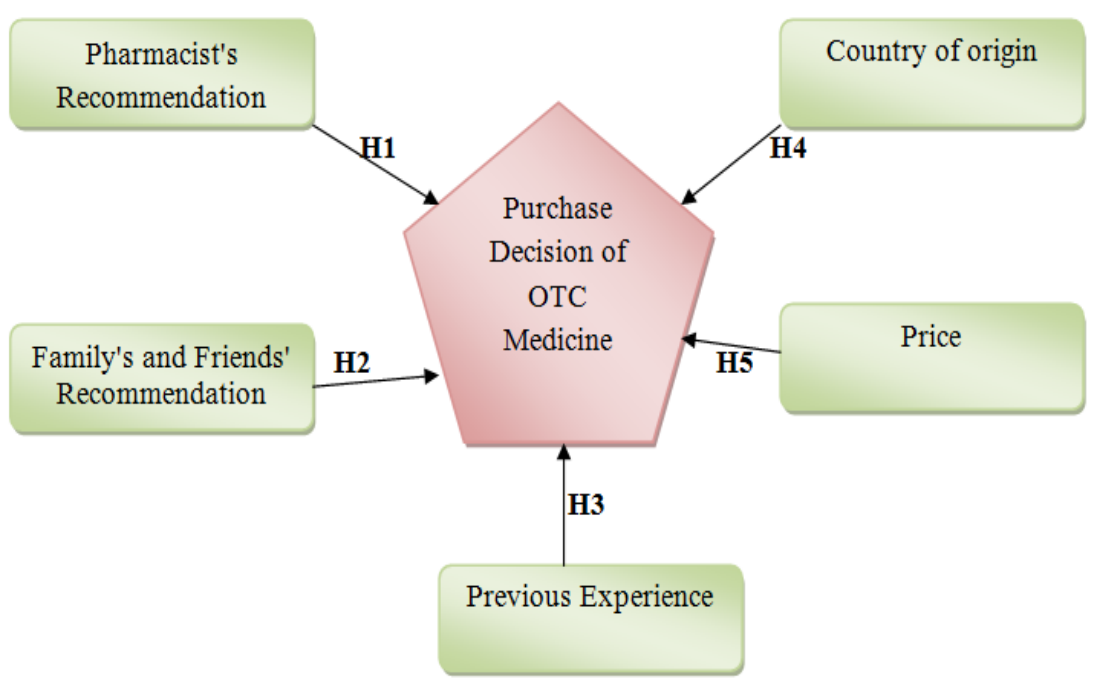

Figure 2: Conceptual Framework [Source: Cîrstea, et al. (2017), Boström (2011), Major and Vincze (2010), Yousif (2016), Haramiova, et al. (2017), Shohel, et al. (2013), Dadhich \& Dixit (2017), Kevrekidis, et al. (2017), Talabă \& Andrei (2010), and Villako, et al. (2012)]

\section{Research Hypothesis}

H1: Pharmacist's recommendation has a positive and significant effect on consumer purchase decision of OTC medicines.

H2: Family and friends' recommendation have positive and significant effect on consumer purchase decision of OTC medicines.

H3: Previous experience has positive and significant effect on consumer purchase decision of OTC medicines.

H4: Country of origin has positive and significant effect on consumer purchase decision of OTC medicines.

H5: Price has positive and significant effect on consumer purchase decision of OTC medicines.

\section{Methodology}

This study was conducted from March 01, 2018 to April 27, 2018 at Addis Ababa, the capital city of Ethiopia. Addis Ababa has 10 Sub cities and 116 Woredas and covers an area of 540 square kilometers. Addis Ababa is the largest city in the country. The total projected population of the city is 3,384,569 with annual growth rate of $3.8 \%$. There are 662,728 households in 628,984 housing units (CSA, 2007). As per the Food, Medicine, health Care Administration and control Authority (FMHACA) of the city, there are 480 community pharmacies in the city.

As a capital city, Addis Ababa is the center of the country's trade activities including the pharmaceutical market. The main reason why the researcher selected Addis Ababa as study area was that the population comes from different regions of Ethiopia; they can represent different culture, religion, political, commercial and economical backgrounds. As a result, the finding of the study can be generalized at country level.

A quantitative research approach was used to test the effect of varies factors on consumer purchase decision of OTC medicines. To achieve the objective of the study, the researcher used both descriptive and explanatory research design to investigate those factors affecting consumers purchase decision of OTC medicine, and the relationship between each independent and dependent variable.

Both primary and secondary data was collected from various sources using data gathering instruments to make the study complete and achieve its predetermined objectives. All sample respondents are the primary source of data while available documents such as books, past literature reviews and relevant articles were used as secondary data.

There are two types of population used in this study. Firstly, this study targeted community pharmacies to intercept the study participants. It is mainly because, community pharmacists are most accessible to the public, an opportunity to become more than medication dispensers. They supply medicines in accordance with a prescription or, when legally permitted, sell them without a prescription. Unlike community pharmacies, the businesses of hospital pharmacies are depending on prescription only medicines that are from respective hospital where they are in (Melton and Lai, 2017). According to the data obtained from Addis Ababa Food, Medicine, and Health Care Administration and Control Authority (AAFMHACA), there are 480 community pharmacies found in Addis Ababa (Internal document contacted on February 26/2018). Secondly, this study considered all 
consumers of OTC medicines from community pharmacies as target population.

The source populations for this study were all consumers of OTC medicines from community pharmacies in Ethiopia.

The target populations for the study were all consumers of over the counter medicines of age $>18$ years from community pharmacies. The list of all community pharmacies was used as a frame to select sample community pharmacies. The list was obtained from Addis Ababa Food, Medicine, and Healthcare Administration and Control Authority (AAFMHACA). A list of each sample community pharmacy was used as a frame to intercept the study participants at convenience.

The researcher used a multi stage sampling technique; first, since there is a sampling frame of community pharmacies in the authorities, simple random sampling technique was used to select a representative sample population of community pharmacies. Since the number of community pharmacies found in Addis Ababa are finite (480) and there is a sample frame, using the formula for finite population (Kothari, 2004), 213 community pharmacies were taken as sample size in the first stage.

In the second stage, a convenience sampling technique was used to have a representative sample population of the study subjects; i.e. over- the- counter medicine consumers. This is because the total populations of overthe counter medicines consumers from community pharmacies of Addis Ababa are too large and are considered infinite and it is difficult to estimate the probability that each respondent in the population has of being included in the sample. Therefore; considering 95\% confidence interval and 5\% margin of error, using infinite population sampling formula (Kothari, 2004), a minimum sample of 384 consumers of OTC medicines was found to be sufficient as the sample size. However, considering minor adjustment for maintaining uniformity in the field operation, a final sample size of $\mathbf{4 2 6}$ OTC medicine consumers were decided to be optimum.

Data collection was conducted by a self-administered questionnaire. The questionnaire was carefully developed in a way that used to measure the impact of the proposed independent variables on the dependent variable. This self-administered questionnaire was developed with a five point Likert scale. The type of questions, form, wording and sequences were also considered carefully.

The questionnaire had two sections. The first section covered the demographic profile of the participants like age, sex, monthly income and educational level. The second section was structured on a Likert scale of 1-5 to show their degree of agreement or disagreement to the sentences about the constructs under study. The questionnaire was adopted from previous studies about the same construct under study and was modified to the OTC medicine without modifying the concepts in the construct. Since the study participants were over the counter medicine consumers of community pharmacies, who are with different educational background, it was necessary to translate the questionnaire into Amharic language before distributing the questionnaire to help easy comprehension and accurate response of respondents.

The questionnaire was evenly distributed throughout randomly selected community pharmacies from first week of March 2018 to second week of April 2018 and consumers were intercepted at the selected community pharmacies immediately after an actual purchase of OTC medicine. The times 12:00PM to 1:30 PM and 5:00 $\mathrm{PM}$ to 8:00PM in the afternoon were chosen since the number of consumers at community pharmacies increases at these times of the day, which will enable the researcher to obtain responses from variety of customers.

\section{Ethical Consideration}

An official letter from Addis Ababa University School of Commerce department of Marketing Management was written to community pharmacies to get permission. In addition, the entire study participant was informed about the purpose of the study and finally their oral consent was obtained before giving the questioner. The information provided by each respondent has been kept confidential and will only be used for research purpose.

\section{Analysis}

Out of 426 questionnaires distributed to targeted respondents, only 409 were complete, valid and appropriate for analysis, which represent $96 \%$ valid response rate.

Reliabilities of the scales were checked after coding and entry of data into SPSS version 23.0. Cronbach's alpha coefficients were computed for each scale to determine the internal consistency reliability of the instruments used in the study. Cronbach's alpha value of 0.60 is considered as in the lower limit of acceptability (Malhotra \& Birks, 2007), and the overall alpha value is 0.894 which shows the highly acceptability of the measurement scales used. 
Table 1: Summary of Reliability Analysis

\begin{tabular}{|c|c|c|}
\hline & \multicolumn{2}{|c|}{ Reliability Statistics } \\
\hline & Cronbach's Alpha & Nof Items \\
\hline Pharmacists recommendation & .857 & 4 \\
\hline Families' and friends' recommendation & .765 & 5 \\
\hline Past experience & .770 & 4 \\
\hline Country of origin & .885 & 5 \\
\hline Price & .711 & 5 \\
\hline Purchase decision & .770 & 5 \\
\hline
\end{tabular}

Source: Survey Result (May, 2018)

As the below Table 4.2 shows, out of 409 respondents, 213 (52.1\%) of them were females and the remaining $196(47.9 \%)$ of the respondents were males. Regarding to age, $164(40.1 \%)$ of the respondents were in the age group of $18-30$ years old while only $16(3.9 \%)$ of the respondents were above 60 years old. This implies that most of OTC medicine consumers were young and adults so that they can be easily addressed by pharmaceutical marketing promotional activities. With respect to educational level, 126(30.8\%) respondents were Bachelor's degree holders while there were only $12(2.9 \%)$ of respondents who have no formal educational background. From the finding, since most of respondents were educated, the researcher concludes that the pharmaceuticals marketers can easily transfer product information and other promotional activities with different communication media. According to the finding, 161(39.4\%) of the respondents have monthly income more than $5,000 \mathrm{birr} / \mathrm{month}$ while only $14(3.4 \%)$ of respondents have monthly income less than 1000birr/month.

Table 2: Demographic Characteristics; Sex, Age, Educational Level, and Monthly income

\begin{tabular}{|cl|c|c|}
\hline \multicolumn{1}{|c|}{ Items } & Frequency & Percent \\
\hline & $18-30$ & 164 & 40.1 \\
& $31-40$ & 131 & 32.0 \\
\multirow{4}{*}{ Age (Year) } & $41-50$ & 64 & 15.6 \\
& $51-60$ & 34 & 8.3 \\
& $>60$ & 16 & 3.9 \\
& Total & 409 & 100.0 \\
\hline \multirow{3}{*}{ Sex } & Male & 196 & 47.9 \\
& Female & 213 & 52.1 \\
& Total & 409 & 100.0 \\
\hline Educational Level & No formal education & 12 & 2.9 \\
& Primary education & 37 & 9.0 \\
& Secondary education & 64 & 15.6 \\
& Diploma & 104 & 25.4 \\
& Degree & 126 & 30.8 \\
& Masters degree \& above & 66 & 16.1 \\
& Total & 409 & 100.0 \\
\hline Monthly Income (Birr) & $<1000$ & 14 & 3.4 \\
& $1001-2000$ & 34 & 8.3 \\
& $2001-3000$ & 41 & 10.0 \\
& $3001-4000$ & 80 & 19.6 \\
& $4001-5000$ & 79 & 19.3 \\
& $>5000$ & 161 & 39.4 \\
& Total & 409 & 100.0 \\
\hline
\end{tabular}

Source: Survey Result (May, 2018)

As it can be seen in Table 4.3, all variables have mean score above average and these shows consumers were considered all independent variables while they decide to purchase OTC medicines. The mean score for Pharmacists recommendation was higher than others. This indicates that respondents were more agreed that pharmacists' recommendation more influenced their purchase decision of OTC medicines. 
Table 3: Descriptive Statistics of the variables

\begin{tabular}{|l|r|r|r|}
\hline \multicolumn{2}{|c|}{ Descriptive Statistics } \\
\hline Pharmacist recommendation & $\boldsymbol{N}$ & Mean & Std. Deviation \\
Family and Friend recommendation & 409 & 3.93 & .819 \\
& & 3.12 & .828 \\
Past Experience & 409 & 3.21 & .909 \\
Country of Origin & 409 & 3.15 & .894 \\
Price & 409 & 3.30 & .661 \\
Purchase Decision & 409 & 3.44 & .617 \\
Valid N (listwise) & 409 & & \\
\hline
\end{tabular}

Source: Survey Result (May, 2018)

As a result, Table 4.4 shows the independent variables are significantly and positively correlated with dependent variable. Price, Country of origin, and Pharmacists' recommendation have positive and significant correlation with purchase decision. This indicates that consumers were highly considered price, country of origin, and pharmacists' recommendation while they decided to purchase OTC medicines.

Table 4: Correlation between the independent variables and the dependent variable

Correlations

\begin{tabular}{|c|c|c|c|c|c|c|c|}
\hline & & $\begin{array}{l}\text { Pharmacists } \\
\text { recommendation }\end{array}$ & $\begin{array}{l}\text { Families' \& } \\
\text { friends' } \\
\text { recommendation }\end{array}$ & $\begin{array}{l}\text { Past } \\
\text { experience }\end{array}$ & $\begin{array}{l}\text { Country } \\
\text { of origin }\end{array}$ & Price & $\begin{array}{l}\text { Purchase } \\
\text { decision }\end{array}$ \\
\hline $\begin{array}{l}\text { Pharmacists } \\
\text { recommendation }\end{array}$ & $\begin{array}{l}\text { Pearson } \\
\text { Correlation } \\
\text { Sig. (2-tailed) } \\
\mathrm{N} \\
\end{array}$ & $\begin{array}{r}1 \\
409 \\
\end{array}$ & $\begin{array}{r}.283 * * \\
.000 \\
409 \\
\end{array}$ & $\begin{array}{r}.284 * * \\
.000 \\
409\end{array}$ & $\begin{array}{r}.163 * * \\
.002 \\
409\end{array}$ & $\begin{array}{r}.401 * * \\
.000 \\
409\end{array}$ & $\begin{array}{r}.617 * * \\
.000 \\
409\end{array}$ \\
\hline $\begin{array}{l}\text { Families' \& friends' } \\
\text { recommendation }\end{array}$ & $\begin{array}{l}\text { Pearson } \\
\text { Correlation } \\
\text { Sig. (2-tailed) } \\
\mathrm{N} \\
\end{array}$ & $\begin{array}{r}.283 * * \\
.000 \\
409 \\
\end{array}$ & $\begin{array}{r}1 \\
409 \\
\end{array}$ & $\begin{array}{r}.480 * * \\
.000 \\
409 \\
\end{array}$ & $\begin{array}{r}.173 * * \\
.001 \\
409 \\
\end{array}$ & $\begin{array}{r}.411 * * \\
.000 \\
409 \\
\end{array}$ & $\begin{array}{r}.345^{* *} \\
.000 \\
409 \\
\end{array}$ \\
\hline $\begin{array}{l}\text { Previous } \\
\text { experience }\end{array}$ & $\begin{array}{l}\text { Pearson } \\
\text { Correlation } \\
\text { Sig. (2-tailed) } \\
\text { N }\end{array}$ & $\begin{array}{r}.284 * * \\
.000 \\
409 \\
\end{array}$ & $\begin{array}{r}.480 * * \\
.000 \\
409 \\
\end{array}$ & $\begin{array}{r}1 \\
409 \\
\end{array}$ & $\begin{array}{r}.304 * * \\
.000 \\
409 \\
\end{array}$ & $\begin{array}{r}.295 * * \\
.000 \\
409 \\
\end{array}$ & $\begin{array}{r}.388 * * \\
.000 \\
409 \\
\end{array}$ \\
\hline Country of origin & $\begin{array}{l}\text { Pearson } \\
\text { Correlation } \\
\text { Sig. (2-tailed) } \\
\mathrm{N}\end{array}$ & $\begin{array}{r}.163 * * \\
.002 \\
409 \\
\end{array}$ & $\begin{array}{r}.173 * * \\
.001 \\
409 \\
\end{array}$ & $\begin{array}{r}.304 * * \\
.000 \\
409 \\
\end{array}$ & $\begin{array}{r}1 \\
409 \\
\end{array}$ & $\begin{array}{r}.324 * * \\
.000 \\
409 \\
\end{array}$ & $\begin{array}{r}.642 * * \\
.000 \\
409 \\
\end{array}$ \\
\hline Price & $\begin{array}{l}\text { Pearson } \\
\text { Correlation } \\
\text { Sig. (2-tailed) } \\
\mathrm{N}\end{array}$ & $\begin{array}{r}.401 * * \\
.000 \\
409 \\
\end{array}$ & $\begin{array}{r}.411 * * \\
.000 \\
409 \\
\end{array}$ & $\begin{array}{r}.295 * * \\
.000 \\
409 \\
\end{array}$ & $\begin{array}{r}.324 * * \\
.000 \\
409 \\
\end{array}$ & $\begin{array}{r}1 \\
409 \\
\end{array}$ & $\begin{array}{r}.720 * * \\
.000 \\
409 \\
\end{array}$ \\
\hline Purchase Decision & $\begin{array}{l}\text { Pearson } \\
\text { Correlation } \\
\text { Sig. (2-tailed) } \\
\text { N }\end{array}$ & $\begin{array}{r}.617 * * \\
.000 \\
409 \\
\end{array}$ & $\begin{array}{r}.345^{* *} \\
.000 \\
409\end{array}$ & $\begin{array}{r}.388 * * \\
.000 \\
409\end{array}$ & $\begin{array}{r}.642 * * \\
.000 \\
409\end{array}$ & $\begin{array}{r}.720 * * \\
.000 \\
409\end{array}$ & $\begin{array}{r}1 \\
409\end{array}$ \\
\hline
\end{tabular}

**. Correlation is significant at the 0.01 level (2-tailed).

Source: Survey Result (May, 2018)

\section{Multiple Regression Analysis}

As depicted in Table 4.7, when overall purchase decision was regressed on overall the five independent variables, the independent variables contribute to statistically significant relationship $(\mathrm{p}<0.01)$ between the dependent variable. $82.3 \%$ of the variation accounted for the dependent variable is due to the combined effect of the independent variables.

Table 5: Model Summary

Model Summary b

\begin{tabular}{|l|r|r|rr|r|}
\hline Model & $\boldsymbol{R}$ & $\boldsymbol{R}$ Square & $\begin{array}{l}\text { Adjusted } \\
\text { Square }\end{array}$ & $\begin{array}{l}\text { Std. Error of the } \\
\text { Estimate }\end{array}$ \\
\hline 1 & $.907 \mathrm{a}$ & & .823 & & .821 \\
\hline
\end{tabular}

a. Predictors: (Constant), price, past experience, country of origin, pharmacists' opinion and recommendation, families' and friends' opinion and recommendation.

b. Dependent Variable: Purchase decision

Source: Survey Result (May, 2018)

Table 4.8 depicted that there is a strong positive and significant relationship between the independent variables (pharmacists' recommendation, price, and country of origin) and dependent variable (purchase 
decision). Since, coefficient of the predictor variables were statistically at $<5 \%$ level of significance, alternative hypotheses related with pharmacists' recommendation, price, and country of origin were accepted.

Though, past experience and families' and friends' recommendation have positive effect on purchase decision of over- the- counter medicine, it is not significant (P- value 0.147 , and 0.155 respectively). Therefore; alternative hypotheses related with past experience and families' and friends' opinion and recommendation were rejected.

Table 6: Regression Analysis of Independent and Dependent Variable

Coefficients $^{\mathbf{a}}$

\begin{tabular}{|c|c|c|c|c|c|c|}
\hline \multirow{2}{*}{ Model } & & \multicolumn{2}{|c|}{$\begin{array}{c}\text { Unstandardized } \\
\text { Coefficients }\end{array}$} & \multirow{2}{*}{$\begin{array}{c}\text { Standardized } \\
\text { Coefficients }\end{array}$} & \multirow[b]{2}{*}{$t$} & \multirow[b]{2}{*}{ Sig. } \\
\hline & & B & Std. Error & & & \\
\hline 1 & (Constant) & .055 & .088 & & .622 & .534 \\
\hline & Pharmacists recommendation & .301 & .017 & .436 & 18.142 & .000 \\
\hline & $\begin{array}{l}\text { Families' and friends' } \\
\text { recommendation }\end{array}$ & .023 & .020 & .030 & 1.139 & .155 \\
\hline & Past experience & .026 & .018 & .038 & 1.454 & .147 \\
\hline & Country of origin & .279 & .019 & .370 & 15.035 & .000 \\
\hline & Price & .402 & .025 & .431 & 16.233 & .000 \\
\hline
\end{tabular}

a. Dependent Variable: Purchase decision

Source: Survey Result (May, 2018)

\section{Analysis of Variance}

As it is depicted in table 4.9, ANOVA tests shows that the regression model results in significantly better prediction of product purchase decision than if we used the mean value of customers' product purchase decision. Table 7: ANOVA

ANOVA $^{\mathrm{a}}$

\begin{tabular}{|l|l|r|r|r|r|r|}
\hline \multicolumn{2}{|l|}{ Model } & Sum of Squares & df & Mean Square & F & Sig. \\
\hline \multirow{4}{*}{1} & Regression & 114.985 & 5 & 22.997 & 336.942 & $.000 \mathrm{~b}$ \\
\cline { 2 - 7 } & Residual & 24.707 & 403 & .068 & & \\
\cline { 2 - 7 } & Total & 139.692 & 408 & & & \\
\hline
\end{tabular}

a. Dependent Variable: Purchase decision

b. Predictors: (Constant), Price, Past experience, Country of origin, Pharmacists opinion and recommendation, Families' and friends' opinion and recommendation

Source: Survey Result (May, 2018)

\section{Discussion}

This study was carried out to answer the researchers' five main questions which were listed in chapter one. Namely, how does pharmacist's recommendation affect consumers purchase decision of OTC medicines? To what extent family's and friends' recommendation affect consumers purchase decision of OTC medicines? How does country of origin affect consumer purchase decision of OTC medicines? How a past experience does affect consumer purchase decision of OTC medicines? And to what extent does price affect consumer purchase decision of OTC medicines?

As a result, the study revealed that pharmacist's recommendation has a positive and significant effect on consumers' purchase decision of OTC medicines with a mean value of 3.93.

This is supported by the finding of Kevrekidis, et al. (2017), which was conducted in Greece that has a mean value 4.31. In addition, the finding is supported by Haramiova, et al. (2017), Talabă and Andreia (2010), Cîrstea, et al. (2017), and Boström (2011). The finding shows that consumers have a deep trust in the knowledge and competency of the pharmaceutical staff, and that they are easily influenced by them. For this consumer segment the pharmaceutical staffs are influencers who shape the consumers' view on different products and affect their final purchase decision. The pharmaceutical staff can influence the range of products that the consumer evaluates as an alternative. If we now consider that many consumers take into consideration and also place their product choice based on the opinion or recommendation from the pharmaceutical staff, the pharmaceutical staff is likely to have a great influence on consumers' purchase decision of products

Even though most of the respondents were relatively high paid, they were highly concerned about the price of OTC medicines. In other words, price also has a positive and significant effect on purchase decision of OTC medicines of consumers. This implies that OTC medicine consumers usually check the price of OTC medicine before buying it. The finding is in accordance with the result of Haramiova, et al. (2017), (Villako, et al., 2012), 
Major and Vincze (2010), Shohel, et al. (2013), and Dadhich \& Dixit (2017) which were conducted in different developed countries especially in Europe and Asia.

Country of origin has a positive and significant effect on consumers' purchase decision of OTC medicines with mean value of 3.15. This result is in line with Kevrekidis, et al. (2017), which was conducted in Greece, which has a mean value 3.63. Shohel, et al. (2013), Dadhich \& Dixit (2017), and Boström (2011) have similar results that explain the positive and significant effect country of origin on consumers' purchase decision of OTC medicines. Furthermore, consumers consider country of origin to be important for choosing OTC medicines. It can be considered that country of origin does guide the decision making process of consumers, after they have taken into consideration other people's input. As it is explained in the above, country of origin received an average of 3.15 which indicates its importance. Based on the finding, the researcher can conclude that there is a segment whose product choice is influenced by the pharmaceutical company's country of origin and not only by product features or others people's opinions.

Several studies; Shohel, et al. (2013), Haramiova, et al. (2017), Yousif (2016), Boström (2011), (Cîrstea, et al., 2017), and Talabă and Andreia (2010) explain that recommendation of family and friends is considered as one of the more important factors that help the consumer choose an OTC medicine. However, this study shows there is a positive relationship between families' and friends' recommendation and purchase decision of OTC medicines even if the relationship is statistically insignificant. This is in contrary to the previously studied related literatures.

It is important for pharmaceutical companies that their product is the first product choice which the consumer makes in that specific product category which is explained by; Shohel, et al. (2013), Haramiova, et al. (2017), Yousif (2016), Boström (2011), (Cîrstea, et al., 2017), and Talabă and Andreia (2010) as nearly all consumers say that they usually buy the same OTC medicine again and again. The most common reason for this purchasing pattern is that they know the product does work and through previous experience they have learnt about the product and that it is a solution to their problem or need. Some customers do not have the time or energy to explore other options and buy the same product again. Unlike to these literatures, previous experience has a positive but insignificant effect on consumers' purchase decision of OTC medicines.

Table 7: Summary of the overall outcome of the research hypothesis

\begin{tabular}{|l|l|l|}
\hline \multicolumn{1}{|c|}{ Hypothesis } & \multicolumn{1}{c|}{ Result } & \multicolumn{1}{c|}{ Reason } \\
\hline $\begin{array}{l}\text { H1: Pharmacist's recommendation has a positive and significant effect on } \\
\text { consumer purchase decision of OTC medicines. }\end{array}$ & Confirmed & $\begin{array}{l}\beta=\mathbf{0 . 4 3 6}, \\
\mathrm{p}<0.05\end{array}$ \\
\hline $\begin{array}{l}\text { H2: Family's and friends' recommendation have positive and significant effect on } \\
\text { consumer purchase decision of OTC medicines. }\end{array}$ & rejected & $\begin{array}{l}\beta=0.030, \\
\mathrm{p}>0.05\end{array}$ \\
\hline $\begin{array}{l}\text { H3: Past experience has positive and significant effect on consumer purchase } \\
\text { decision of OTC medicines. }\end{array}$ & rejected & $\begin{array}{l}\beta=0.038, \\
\mathrm{p}>0.05\end{array}$ \\
\hline $\begin{array}{l}\text { H4: Country of origin has positive and significant effect on consumer purchase } \\
\text { decision of OTC medicines. }\end{array}$ & Confirmed & $\begin{array}{l}\beta=\mathbf{0 . 3 7 0}, \\
\mathrm{p}<0.05\end{array}$ \\
\hline $\begin{array}{l}\text { H5: Price has positive and significant effect on consumer purchase decision of } \\
\text { OTC medicines. }\end{array}$ & Confirmed & $\begin{array}{l}\beta=\mathbf{0 . 4 3 1}, \\
\mathrm{p}<0.05\end{array}$ \\
\hline
\end{tabular}

Source: Survey Result (May, 2018)

\section{Conclusion}

As per the finding, pharmacist's recommendation, price, and country of origin of OTC medicines have positive and significant effect on consumers' purchase decision. Thus, consumers' purchase decisions of OTC medicines were mainly determined by the pharmacist's recommendation, price, and country of origin of OTC medicines. Though, past experience and family's and friends' recommendation have positive effect on consumers' purchase decision, it is not statistically significant.

\section{Recommendations}

Depending on the findings and conclusions made, the researcher forwards four main recommendations. These are;

1. Marketers of OTC medicines especially, wholesalers and importers could benefit from considering community pharmacists as main targets for their promotional activities such as, new OTC medicine launch, continuous medical education (CME) as well as detailing (personal selling).

2. OTC medicines wholesalers and importers could also benefit from focusing on their pricing strategies so as to have competitive advantages and manage needs of their consumers.

3. OTC medicine marketers could also capitalize on the country of origin for their products in their strategies through different promotional activities which targets professionals who have direct contact with consumers. This is because commercial advertising of pharmaceutical products is not yet practical in Ethiopia. 
4. Lastly, the researcher recommends further research on previous experience and families' \& friends' recommendation to examine their effect on purchase decision of OTC medicine.

\section{Limitation and Suggestion for Future Research}

1. This study not examined the effect of demographic characteristics on purchase decision of OTC medicines. Therefore, researchers in the future will examine their effects on purchase decision of OTC medicines.

2. This study not included factors like packaging, and company profile as independent variables. Therefore, future research can be carried out on these variables to examine their effects on purchase decision of OTC medicines.

3. Only OTC medicine consumers of Addis Ababa were considered as target population. As a result, the finding might not represent the purchase decision of OTC medicines consumers of the whole Ethiopia. Therefore; additional studies of the same topic shall be conducted in different regions of the country.

4. Finally, since convenient sampling technique was used, the result might not explain OTC medicines purchase decision of even Addis Ababa consumers.

\section{References}

Abdissa A. \& Anbessa B., 2015. Assessment of Self-medication Practice and Drug Storage on Private Pharmacy Clients in Jimma town, Oromia, South west Ethiopia. ARC Journal of Pharmaceutical Sciences (AJPS) Volume 1, Issue 1, PP 20-32 www.arcjournals.org Accessed: 09-01-2018 07:27 UTC

Andualem, T., Kafil, (1995). Retrospective drug use study using prescribing indicators in 32 health Facilities. Ethiopian Pharmaceutical Journal, Vol. 13, pp. 54-61

Asamoah E. S., Chovancova M. (2011) "The influence of price endings on Consumer behavior: an application of the psychology of perception", Acta univ. agric. et silvic. Mendel. Brun. Vol. LIX, No. 7, pp. 29-38

Azimi G. and Shabani M. (2016) "The effect of green marketing mix on purchase decision-making styles of customers", International Journal of Advanced Biotechnology and Research (IJBR). Vol-7, Special IssueNumber2. http://www.bipublication.com

Azimi, G. and Shabani, M. 2016. The effect of green marketing mix on purchase decision-making styles of customers. International Journal of Advanced Biotechnology and Research (IJBR). Vol-7, Special IssueNumber2 pp797-805 (http://www.bipublication.com)

Babu M. (2007) "Factors contributing to the purchase of Over the Counter (OTC) drugs in Bangladesh: An Empirical study", the internet journal of third world medicine. vol.6, Number 2

Battistoni E., Colladon A. F., and Puglia P.(2014) "Exploiting the Potential Value of Over-the-counter Drugs Through Brand Equity: An Analytic Network Process Approach; International Journal of Engineering Business Management.

Belch, G. E., \& Belch, M. A. (2003). Advertising and Promotion: An Integrated Marketing Communications Perspective. 6th. ed. ed. McGraw-Hill Companies.

Bettman J.R., (1979) "An Information Processing Theory of Consumer Choice”, Journal of Marketing, Vol. 43, No. 3, pp. 124-126 http://www.jstor.org/stable/1250155

Bhattacherjee, A. (2012). Social science research: principles, methods, and practices 2nd ed, A free textbook published under the Creative Commons Attribution 3.0 License The Global Text Project is funded by the Jacobs Foundation, Zurich, Switzerland.

Bond C., n.d. The over-the-counter pharmaceutical market policy and practice. Eurohealth Vol 14 No 3

Boström, K. (2011) "Consumer behavior of pharmacy customers; Choice of pharmacy and OTC medicines."

Brass, E.P., R. Lofstedt and O. Renn (2011). Improving the Decision-Making Process for Non-prescription Drugs: A Framework for Benefit Risk Assessment. State of Art, Nature publishing group, Journal of Clinical pharmacology \& Therapeutics. Vol. 90. No. 6.

Carrigan M., Attalla A. (2001) "The myth of the ethical consumer; do ethics matter in purchase behaviour?" Journal of Consumer Marketing, 18 (7), 560-578.

Central Statistical Authority (CSA) of Ethiopia, (2007) the Population and Housing Census of Ethiopia. Analytical Report at National Level. Addis Ababa, Ethiopia: http://www.Ethiodemographyandhealth.org (Accessed 02 December, 2017)

Cîrstea S.D., Teselios M.C., and Iancu A.I. (2017) “Analysis of Factors that Influence OTC Purchasing Behavior;" Springer International Publishing. International Conference on Advancements of Medicine and Health Care through Technology.' Vol. 59

Covington, T.R. The pharmacist as nonprescription drug therapy manager: let's seize the opportunity. J Am Pharm Assoc (Wash). 2002; 42(3):518-519.

Dadhich A. \& Dixit K. (2017) "Consumer Selection and Buying Behavior Towards Over- the- Counter (OTC) Medicine”, Apeejay-Journal of Management Sciences and Technology.’ 4 (2) 
Denise E.D., Jisu H., Leonard N. R., and Soontae A., (2010) "The state of public research on over-the-counter drug advertising", International Journal of Pharmaceutical and Healthcare Marketing, Vol. 4Issue: 3, pp.208-231, https://doi.org/10.1108/17506121011076156

Donohue J. M., Marsa C., \& Resenthal M. B., (2007) “A decade of direct-to consumer advertising of prescription drugs", the New England journal of medicine, 357(7), p. 673-681.

Ethiopia Federal Ministry of Health (FMoH), (2014). Ethiopia's Fifth National Health Accounts 2010/2011.

Federal democratic republic of Ethiopia ministry of health and world health organization. (2003). Assessment of the pharmaceutical sector in (http://www.who.int/medicines/areas/coordination/Ethiopiapharmaceutical.pdf)

Federal Ministry of Health and Ministry of Industry; National Strategy and Plan of Action for Pharmaceutical Manufacturing Development in Ethiopia, 2015: Developing the pharmaceutical industry and improving access.

Food, Medicine and Health Care Administration and Control Authority (FMHACA), 2012. Over-the- counter medicines list for Ethiopia. http://www.fmhaca.gov.et (Access date; Nov 19/2017)

Frost \& Sullivan (2012). Analysis of the Pharmaceutical industry in Ethiopia.

Furaiji F., Łatuszyńska M., and Wawrzyniak A. (2012) "An Empirical Study of the Factors influencing Consumer Behaviour in the Electric Appliances Market”, vol.6 issue.3 P.76-86

Girma B., Diriba A., Zerihun A., Derbew F., Abera H., Mussie G., Gebremedhin S., Naod G., Raghavendra Y., and Abrham W., (2011) "Self-Medication Practices among Health Sciences Students: The Case of Mekelle University", Journal of applied pharmaceutical science. Vol. 01 (10) p. 183-189. www.japsonline.com (Access date: 12 October 2017)

Gogoi B. J. (2013) "Study of antecedents of purchase intention and its effect on brand loyalty of private label brand of apparel", International Journal of Sales \& Marketing. Vol. 3, Issue 2. Pp 73-86.

Hair, J.F., Anderson, R.E., Tatham, R.L. and Black, W.C. (1998). Multivariate data analysis. $5^{\text {th }}$ ed. Englewood Cliffs, NJ: Prentice Hall inc.

Haramiova Z., Kobliskova Z., and Soltysova J. (2017) "Purchase of prescription and OTC medicines in Slovakia: factors influencing patients' expectations and satisfaction”, Brazilian Journal of Pharmaceutical Sciences.' Vol. 53(1)

Ho, R. (2006). Handbook of Univariate and Multivariate Data Analysis and Interpretation with SPSS. New York: Taylor \& Francis Group.

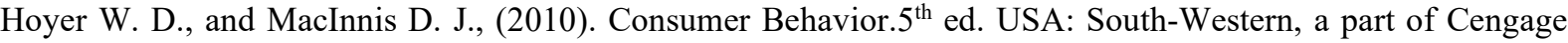
Learning.

IMS Health Africa, 2013. A ripe opportunity Understanding the pharmaceutical market opportunity and developing sustainable business models in Africa. (http://www.imshealth.com Accessed January 23, 2017.

Keller, K., (2001) Building customer-based brand equity: creating brand resonance requires carefully sequenced brand-building efforts. Marketing Management, 10(2)

Kevrekidis P., Minarikova D., Markos A., Malovecka I., and Minarik P. (2018) "Community pharmacy customer segmentation based on factors influencing their selection of pharmacy and over-the-counter medicines", Saudi Pharmaceutical Journal. Vol. 26, p. 33-43

Khan RA. (2011). Self-medication with antibiotics: practices among pakistani students in Sweden and Finland. Available at: http://sh.diva-portal.org/smash/get/diva2:452461/

Kotecki, J.E., (2002) "Factors related to pharmacists' over-the-counter recommendations", Journal of Community Health, Vol. 27, No. 4

Kothari, C.R. (2004).Research Methodology Methods \& Techniques, Second Edition, New Delhi: New Age International Publisher

Kotler P. and Keller K.L., (2012). Marketing Management. 14th ed. Pearson Education, Inc., Prentice Hall

Kotler, P. and Armstrong, G. (2012) Principles of marketing, $14^{\text {th }}$ ed., New Jersey: Pearson Education Limited

Kotler, P., Wong, V., \& Saunders, J., Armstrong, G., (2005). Principles of marketing. 4th edition. Harlow. Pearson Education Limited.

Laroche M., Papadopoulos N., Heslop L.A. and Mourali M.,(2005) "The influence of country image structure on consumer evaluations of foreign products", International Marketing Review

Major C. and Vincze, Z. (2010) "Consumer habits and interests regarding non-prescription medications", Family Practice- an international journal. Vol 27 Pp 333-338 Available at: https://academic.oup.com/fampra/article. (Accessed date 09 October 2017)

Malhotra, N. K., \& Birks, D. F. (2007). Marketing Research: An Applied Approach (Third European Edition Ed.). England: Prentice Hall, Inc., a Pearson Education company. Management, Vol XI No. MB.

Mamun A., Rahman M.R., and Robel S. D., (2014) “A Critical Review of Consumers' Sensitivity to Price: Managerial and Theoretical Issues", Journal of International Business and Economics. Vol. 2, No. 2, pp. 0109 
Marczyk G., DeMatteo D., and Festinger D. (2005), Essentials of Research Design and Methodology, Published by John Wiley \& Sons, Inc., Hoboken, New Jersey, Published simultaneously in Canada.

Melton, B.L. and Lai Z. (2017) "Review of community pharmacy services: what is being performed, and where are the opportunities for improvement?" Integrated Pharmacy Research and Practice.Vol.6, pp. 79-89

Mohammed B., (2017) "Self-medication practice in Ethiopia: a systematic review", http://www.dovepress.com/patient-preference-and-adherence

Mossa D., Wabe N., and Angamo M. (2012). Self-Medication with Antibiotics and Anti-malarial in the community of Silte Zone, South Ethiopia. TAF Prev Med Bull 11: 529-536.

Over-the-counter drugs through brand equity: An analytic network process approach", International journal of business management. www.intechopen.com

Pallant, J. (2001). SPSS Survival Manual; A step by step guide to data analysis. Version 10 Buckingham, Philadelphia. www.openup.co.uk/spss

Pappu R., Quester P.G., and Cooksey R.W., (2006) "Consumer based brand equity and country of origin relationships: Some empirical evidence”, European Journal of Marketing, Vol. 40 Issue: 5/6, pp.696-717. https://doi.org10.1108/03090560610657903

Paul R. (2015) “Role of community pharmacists in patients' selfcare and selfmedication” Integrated Pharmacy Research and Practice, 4 .pp. 5765.

Pride, W. M., Ferrell, O. C. (2007). Foundations of Marketing ( $2^{\text {nd }}$ ed.). Boston, MA: Houghton Miffin Company.

QuintilesIMS Institute. 2016. Outlook for Global Medicines through 2021. Parsippany, USA. www.quintilesimsinstitute.org

Saunders, M., Lewis, P., \& Thornhill, A. (2009). Research Methods for Business Students (5th ed. ed.). Harlow, England: Pearson Education Limited.

Saydan R. (2013) "Relationship between Country of Origin Image and Brand Equity: An Empirical Evidence in England Market", International Journal of Business and Social Science. Vol. 4 No. 3

Shohel M., Islam T., Al-Amin M., Islam A., and Rahman M.M. (2013) "Investigation of Consumer Attitudes, Intentions and Brand Loyal Behavior on the OTC Drugs in Bangladesh", British Journal of Pharmaceutical Research'. Vol. 3(3): 454-464

Solomon W. and Abebe G. (2003). Practice of self-medication in Jimma Town. Ethiopian journal of health development.

Solomon, M., Bamossy, G., Askegaard, S. and Hogg, M.K. (2006) Consumer behaviour: a European perspective, 3rd ed., Harlow: Financial Times.

Takhire M., and Joorshari T., (2015) "Evaluation of Effective factors on Customer Decision-making process in the online environment", International journal of managing public sector information and communication technologies (ijmpict), Vol. 6, no. 3

Talabă E. and Andrei G. (2010) "Facets of pharmacists' recommendation on over-the-counter market in Romania" American Journal of Lifestyle Medicine vol. 1: pp. 490 - 498.

Tewodros E., Abebe W., Tirsit R., Mulugeta T., and Eshetu M., (2015). Understanding towards Non-Prescription Medicines among Jimma Town Drug Retail Outlets' Customers, Ethiopia. International Journal of Research in Medical and Health Sciences. Vol. 5. No.01 http://www.ijsk.org/ijrmhs.html

Tisman, A. 2015. The Rising Tide of OTC in Europe: Trends, Challenges and New Potential in a Rapidly Evolving Market.

Villako P., Volmer D., and Raal A., (2012) "Factors influencing purchase of and counseling about prescription and OTC medicines at community pharmacies", Polish Pharmaceutical Society. Vol. 69 No. 2 pp. 335ñ340,

Vol. 22 No. 1, 2005 pp. 96-115 . www.emeraldinsight.com/0265-1335.htm

Wieringa E.J., Reber C.K., Leeflang P., (2015) "Improving pharmacy store performance: the merits of over-thecounter drugs", European Journal of Marketing, Vol. 49 Issue: 7/8, pp.1276-1299, https://doi.org/10.1108/EJM-06-2013-0331

World Health Organization (WHO), the world health report (1998).

Yousif R. O., (2016) "The factors affecting on decision making to Purchase medications without a prescription", International Journal of Sales \& Marketing Management Research and Development. Vol. 6, Issue 2. Pp 1930

Zander K., Hamm, U. (2011) "Information search behavior and its determinants: the case of ethical attributes of organic food", International journal of consumer studies.

\section{Dear Respondent;}

Annex 1

\section{Questionnaire (English version)}

First of all I would like to thank you for your valuable cooperation. I am doing a paper for the fulfillment of a Masters degree in the Arts of Marketing Management. This research focuses on factors affecting consumer 
purchase decision of over- the- counter medicine of community pharmacies in Ethiopia. The information you provide will only be used for the results of the study and it is strictly confidential. Please do not write your contact details on the questionnaire. Thanks for your cooperation again.

Meseret Wube (Mob. +251913989489)

\section{Part I: General Information}

Please put an " $\mathrm{X}$ " mark of your choice on the space provided.

1. What is your age (in year?)
$1.18-30$
2. $31-40$
3. $41-50$
4. $51-60$
5. $>60$

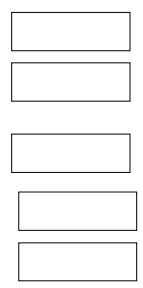

2. Sex
1. Male
2. Female

3. Educational Level

1. No formal education

2. Primary School completed

3. High School completed

4. Diploma

5. Degree

6. Masters Degree and above

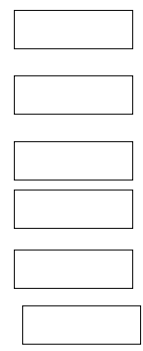

4. Your monthly income (in Birr)
1. $<1000$
2. 1001- 2000
3. 2001- 3000
4. 3001- 4000
5. 4001- 5000
6. $>5000$

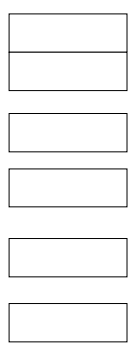

\section{Part II}

Dear Respondent;

First of all I would like to thank you for your valuable cooperation. I am doing a paper for the fulfillment of a Masters degree in the Arts of Marketing Management. This research focuses on factors affecting consumer purchase decision of over- the- counter medicine of community pharmacies in Ethiopia. The information you provide will only be used for the results of the study and it is strictly confidential. Please do not write your contact details on the questionnaire. Thanks for your cooperation again.

Instructions: Please indicate your degree of agreement or disagreement against each question by encircling the appropriate number (where, 1: Strongly disagree, 2: Disagree, 3: Neutral, 4: Agree, and 5: Strongly agree). N.B. Over- the- counter medicine is a medicine that can be purchased from pharmacy without prescription. 


\begin{tabular}{|c|c|c|c|c|c|c|}
\hline$S . N$ & Factors & 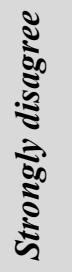 & 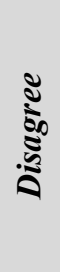 & 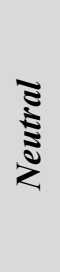 & $\frac{\pi}{\rho^{2}}$ & 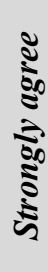 \\
\hline \multicolumn{7}{|c|}{ Pharmacist's recommendation (PR) } \\
\hline PR 1 & $\begin{array}{l}\text { I have a trust on pharmacist's recommendation of over- the- counter } \\
\text { medicines. }\end{array}$ & 1 & 2 & 3 & 4 & 5 \\
\hline PR 2 & $\begin{array}{l}\text { I have been buying an over- the- counter medicine according to } \\
\text { pharmacist's recommendation. }\end{array}$ & 1 & 2 & 3 & 4 & 5 \\
\hline PR 3 & $\begin{array}{l}\text { I repeat buying a medicine which the pharmacist described to me } \\
\text { and gave me good results. }\end{array}$ & 1 & 2 & 3 & 4 & 5 \\
\hline PR 4 & $\begin{array}{l}\text { I have an experience of buying over- the- counter medicine which } \\
\text { the pharmacist recommended me. }\end{array}$ & 1 & 2 & 3 & 4 & 5 \\
\hline \multicolumn{7}{|c|}{ Families' and Friends recommendation (FFR) } \\
\hline FFR 1 & $\begin{array}{l}\text { I have been buying over- the- counter medicine of which I have } \\
\text { heard from my friend and/or my family. }\end{array}$ & 1 & 2 & 3 & 4 & 5 \\
\hline FFR 2 & $\begin{array}{l}\text { I have a trust on family member's experiences regarding over- the- } \\
\text { counter medicines. }\end{array}$ & 1 & 2 & 3 & 4 & 5 \\
\hline FFR 3 & $\begin{array}{l}\text { I have experience of buying a brand of over- the- counter medicine } \\
\text { that my family members recommended me without consulting the } \\
\text { pharmacist. }\end{array}$ & 1 & 2 & 3 & 4 & 5 \\
\hline FFR 4 & $\begin{array}{l}\text { The information I obtain from my family members and friends } \\
\text { encourage me to buy over- the- counter medicine. }\end{array}$ & 1 & 2 & 3 & 4 & 5 \\
\hline FFR 5 & $\begin{array}{l}\text { I repeat buying an over-the-counter medicine that my family } \\
\text { members and friends described to me and gave me good results. }\end{array}$ & 1 & 2 & 3 & 4 & 5 \\
\hline \multicolumn{7}{|c|}{ Previous Experience ( $P E)$} \\
\hline PE 1 & $\begin{array}{l}\text { I prefer to purchase a brand of over-the-counter medicine that I have } \\
\text { previously purchased. }\end{array}$ & 1 & 2 & 3 & 4 & 5 \\
\hline PE 2 & I always buy the same brand of over-the-counter medicine. & 1 & 2 & 3 & 4 & 5 \\
\hline PE 3 & $\begin{array}{l}\text { I am willing to pay more for an over-the-counter medicine I have had a } \\
\text { good experience with. }\end{array}$ & 1 & 2 & 3 & 4 & 5 \\
\hline PE 4 & $\begin{array}{l}\text { I will buy different brands of over- the- counter medicine because I } \\
\text { want variation. }\end{array}$ & 1 & 2 & 3 & 4 & 5 \\
\hline \multicolumn{7}{|c|}{ Country-of-Origin (COO) } \\
\hline $\mathrm{COO} 1$ & $\begin{array}{l}\text { I like considering its country of origin while I purchase an over- } \\
\text { the- counter medicine. }\end{array}$ & 1 & 2 & 3 & 4 & 5 \\
\hline $\mathrm{COO} 2$ & $\begin{array}{l}\text { I use country-of-origin as a reference to evaluate quality of an over- } \\
\text { the- counter medicine among brands. }\end{array}$ & 1 & 2 & 3 & 4 & 5 \\
\hline COO 3 & $\begin{array}{l}\text { I will purchase over- the- counter medicines from certain country to } \\
\text { enhance my self-image. }\end{array}$ & 1 & 2 & 3 & 4 & 5 \\
\hline $\mathrm{COO} 4$ & $\begin{array}{l}\text { I believe purchasing over- the- counter medicines from certain } \\
\text { country will enhance my social status and pride. }\end{array}$ & 1 & 2 & 3 & 4 & 5 \\
\hline COO 5 & $\begin{array}{l}\text { I will purchase an over- the- counter medicine, if it is from a } \\
\text { country-of-origin which I like. }\end{array}$ & 1 & 2 & 3 & 4 & 5 \\
\hline \multicolumn{7}{|c|}{ Price $(P)$} \\
\hline $\mathrm{P} 1$ & I am very concerned about the price of the over- the- counter medicine. & 1 & 2 & 3 & 4 & 5 \\
\hline $\mathrm{P} 2$ & $\begin{array}{l}\text { I will continue buying over- the- counter medicine which I know so far } \\
\text { even though it increases its price. }\end{array}$ & 1 & 2 & 3 & 4 & 5 \\
\hline P3 & $\begin{array}{l}\text { I will switch to another brand of over- the- counter medicine if the price } \\
\text { is increased. }\end{array}$ & 1 & 2 & 3 & 4 & 5 \\
\hline P4 & $\begin{array}{l}\text { I will compare the prices of over- the- counter medicine among brands } \\
\text { while I want to purchase. }\end{array}$ & 1 & 2 & 3 & 4 & 5 \\
\hline P5 & I will buy the cheapest over- the- counter medicine. & 1 & 2 & 3 & 4 & 5 \\
\hline
\end{tabular}




\begin{tabular}{|c|c|c|c|c|c|c|}
\hline \multicolumn{7}{|c|}{ Purchase decision (PD) } \\
\hline PD 1 & $\begin{array}{l}\text { I decide to buy over- the- counter medicine upon pharmacist's } \\
\text { recommendation. }\end{array}$ & 1 & 2 & 3 & 4 & 5 \\
\hline PD 2 & $\begin{array}{l}\text { I decide to buy over- the- counter medicine upon families' and friends' } \\
\text { recommendation. }\end{array}$ & 1 & 2 & 3 & 4 & 5 \\
\hline PD 3 & $\begin{array}{l}\text { I decide to buy over- the- counter medicine through my own } \\
\text { experience. }\end{array}$ & 1 & 2 & 3 & 4 & 5 \\
\hline PD 4 & $\begin{array}{l}\text { I decide to buy over- the- counter medicine by considering its country } \\
\text { of origin. }\end{array}$ & 1 & 2 & 3 & 4 & 5 \\
\hline PD 5 & I decide to buy over- the- counter medicine by considering its price & 1 & 2 & 3 & 4 & 5 \\
\hline
\end{tabular}

\title{
Thank you for your participation!
}

\author{
Annex 2 \\ Questionnaire (Amharic version)

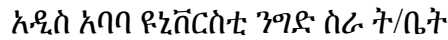

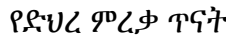

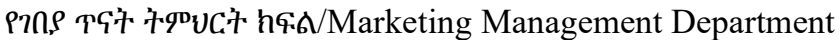

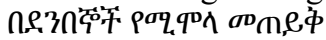

W.

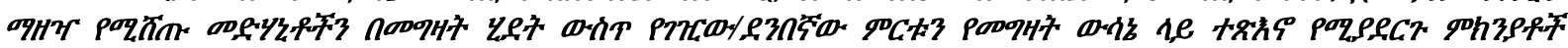
(Factors Affecting Consumers' Purchase Decision of Over- the-Counter Medicines) तबס

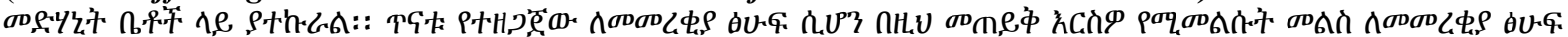

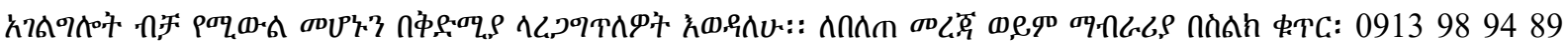

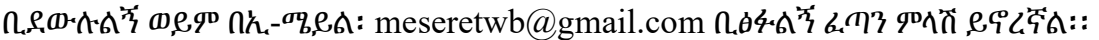

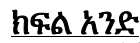

ถ̀n

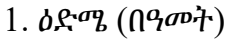

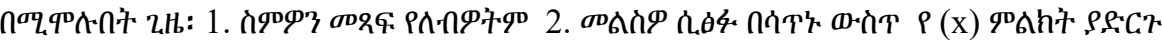
$1.18-30$
2. $31-40$
$3.41-50$
4. $51-60$
5. $>60$

2. 9 .
1. $\omega_{3} e^{-1}$

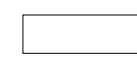
2. ถ่า

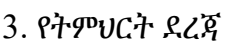

1. Pad

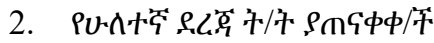

3.

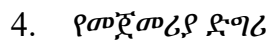

5. $\mathrm{PU}$ Иम

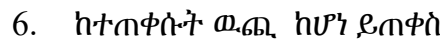

4. $9 \omega \mathrm{C} 7 \mathrm{n}(\mathrm{\cap} \cap \mathrm{C})$
1. h1000 ९ל̀
2. $1001-2000$
3. $2001-3000$
4. $3001-4000$
5. $400-5000$
6. $\mathrm{n} 5000$ ก1,
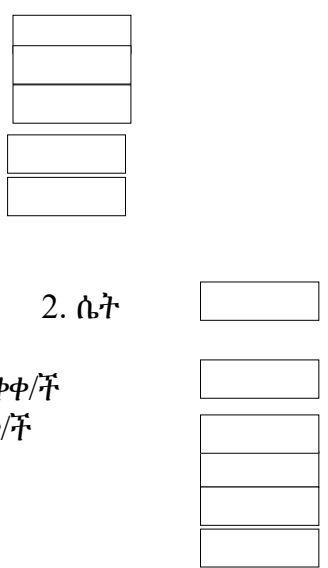

\section{h\$s u.nt}

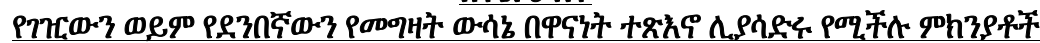

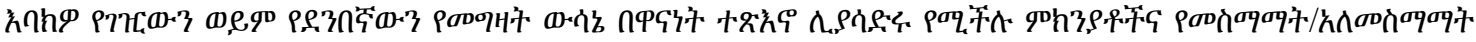

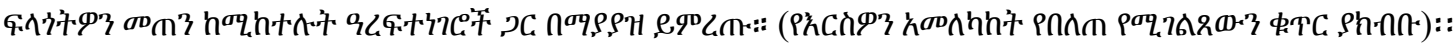




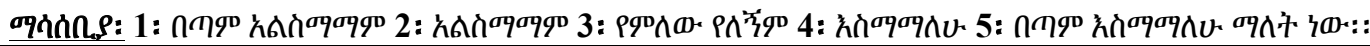

\begin{tabular}{|c|c|c|c|c|c|c|}
\hline \multicolumn{2}{|c|}{ t: } & ลू & हू & $\frac{2}{2} \frac{2}{2}$ & है & हู है \\
\hline \multicolumn{7}{|c|}{ 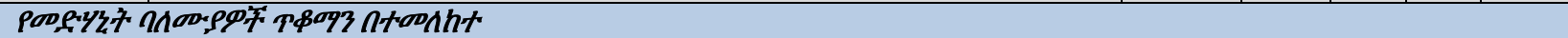 } \\
\hline 1 & 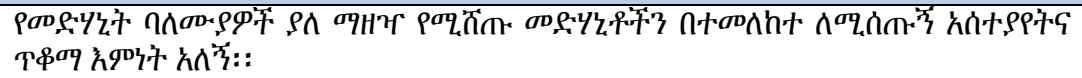 & 1 & 2 & 3 & 4 & 5 \\
\hline 2 & 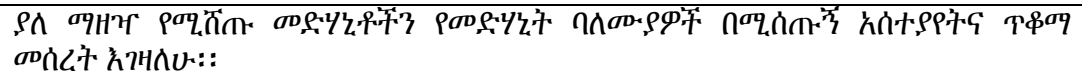 & 1 & 2 & 3 & 4 & 5 \\
\hline 3 & 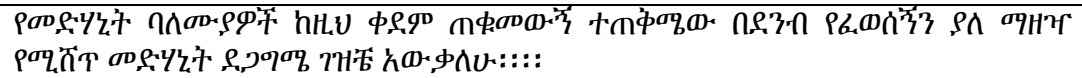 & 1 & 2 & 3 & 4 & 5 \\
\hline 4 & 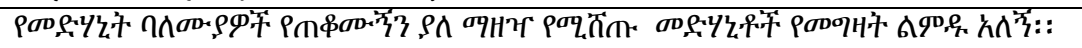 & 1 & 2 & 3 & 4 & 5 \\
\hline \multicolumn{7}{|c|}{ 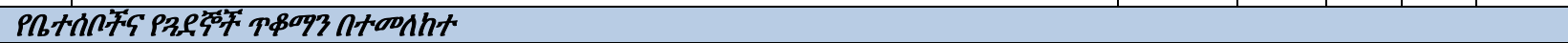 } \\
\hline 1 & 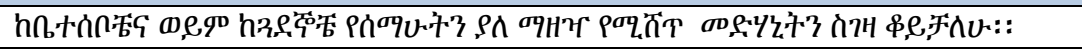 & 1 & 2 & 3 & 4 & 5 \\
\hline 2 & 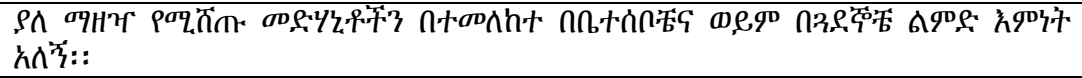 & 1 & 2 & 3 & 4 & 5 \\
\hline 3 & 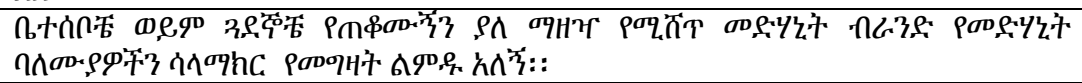 & 1 & 2 & 3 & 4 & 5 \\
\hline 4 & 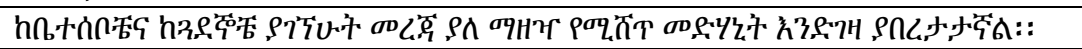 & 1 & 2 & 3 & 4 & 5 \\
\hline 5 & 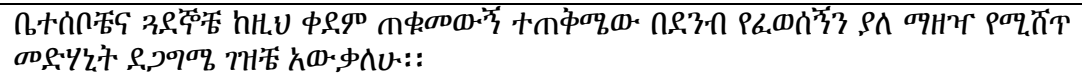 & 1 & 2 & 3 & 4 & 5 \\
\hline \multicolumn{7}{|c|}{ 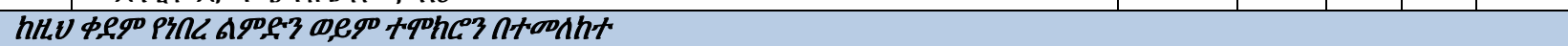 } \\
\hline 1 & 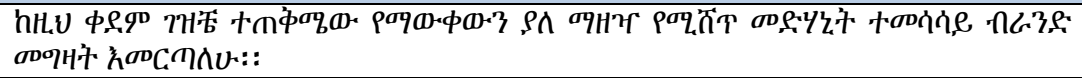 & 1 & 2 & 3 & 4 & 5 \\
\hline 2 & 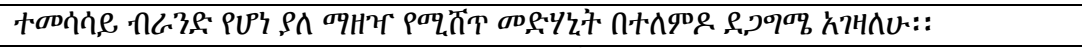 & 1 & 2 & 3 & 4 & 5 \\
\hline 3 & 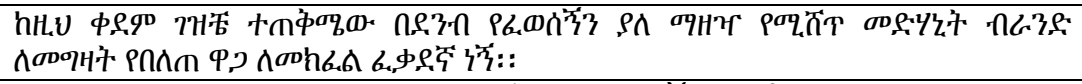 & 1 & 2 & 3 & 4 & 5 \\
\hline 4 & 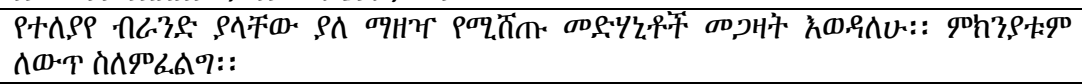 & 1 & 2 & 3 & 4 & 5 \\
\hline \multicolumn{7}{|c|}{ 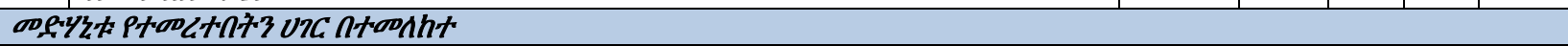 } \\
\hline 1 & 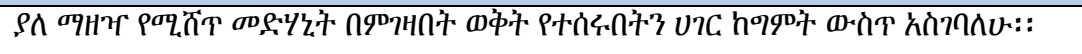 & 1 & 2 & 3 & 4 & 5 \\
\hline 2 & 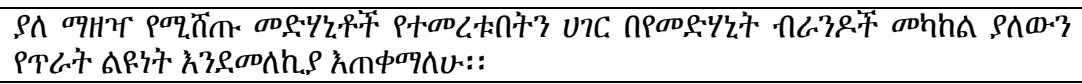 & 1 & 2 & 3 & 4 & 5 \\
\hline 3 & 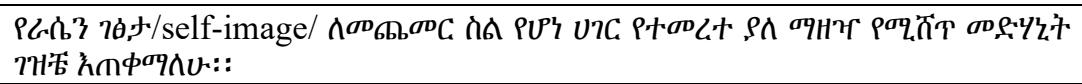 & 1 & 2 & 3 & 4 & 5 \\
\hline 4 & 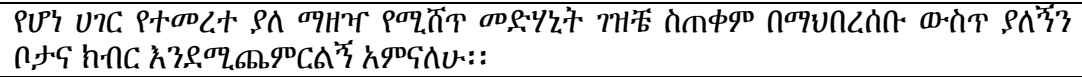 & 1 & 2 & 3 & 4 & 5 \\
\hline 5 & 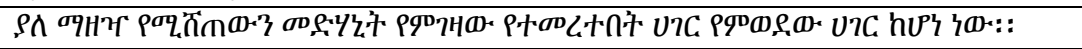 & 1 & 2 & 3 & 4 & 5 \\
\hline \multicolumn{7}{|c|}{ 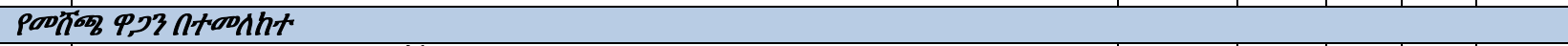 } \\
\hline 1 & 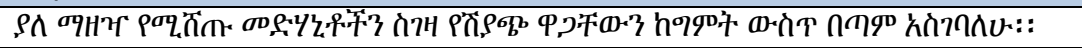 & 1 & 2 & 3 & 4 & 5 \\
\hline 2 & 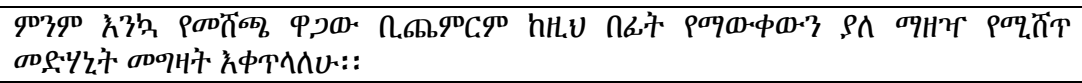 & 1 & 2 & 3 & 4 & 5 \\
\hline 3 & 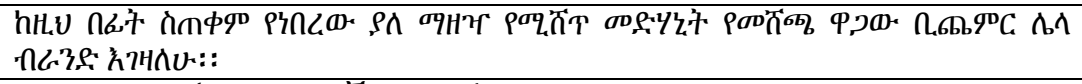 & 1 & 2 & 3 & 4 & 5 \\
\hline 4 & 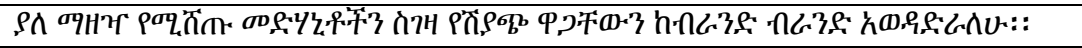 & 1 & 2 & 3 & 4 & 5 \\
\hline 5 & 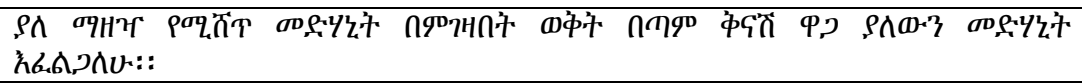 & 1 & 2 & 3 & 4 & 5 \\
\hline \multicolumn{7}{|c|}{ PODqHक D.ib3 ntoonht } \\
\hline 1 & 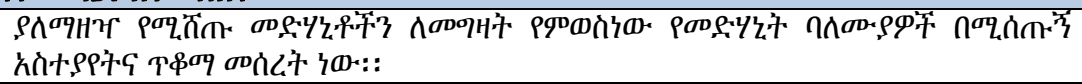 & 1 & 2 & 3 & 4 & 5 \\
\hline 2 & 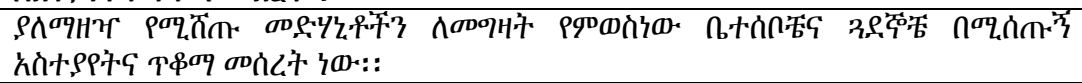 & 1 & 2 & 3 & 4 & 5 \\
\hline 3 & 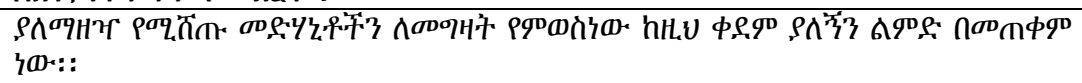 & 1 & 2 & 3 & 4 & 5 \\
\hline 4 & 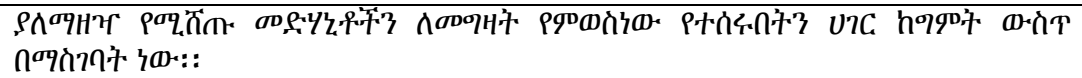 & 1 & 2 & 3 & 4 & 5 \\
\hline 5 & 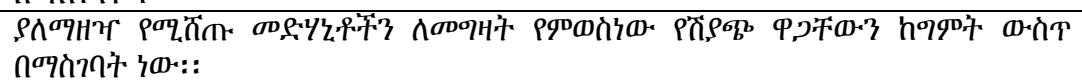 & 1 & 2 & 3 & 4 & 5 \\
\hline
\end{tabular}




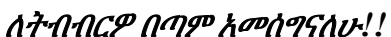

Annex 3

Number of Community Pharmacies in Addis Ababa

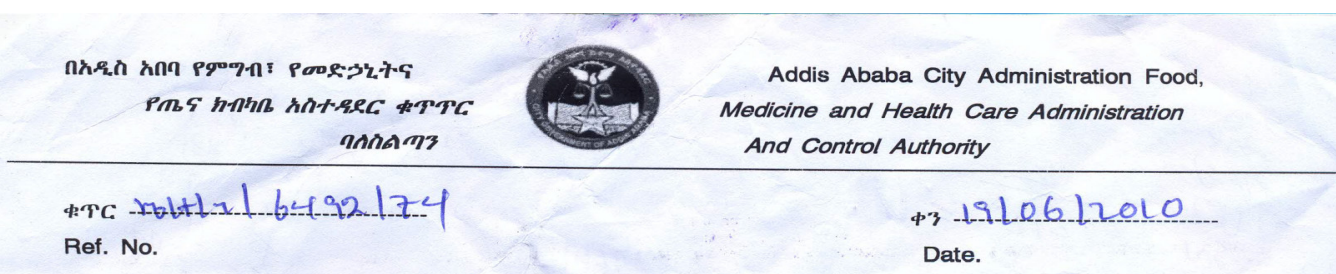

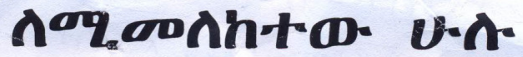

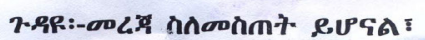

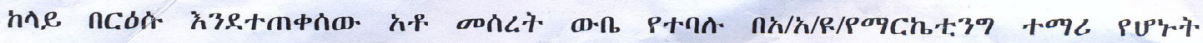

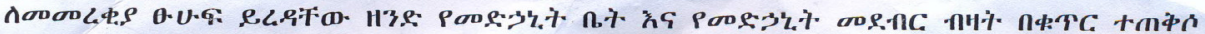

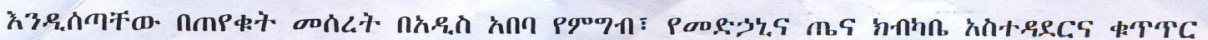

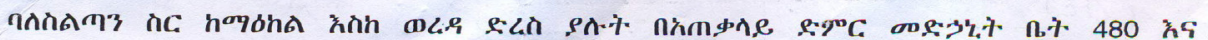

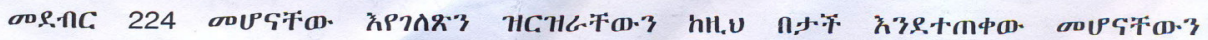
ล3าล

\begin{tabular}{|c|c|c|c|}
\hline T.中 & Ph/ht.09 ngo & 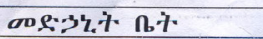 & 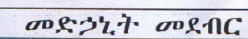 \\
\hline 1 & $n A b_{n}$ PGLP. & 58 & $2=$ \\
\hline 2 & $h L_{0} g_{1}$ & 25 & 12 \\
\hline 3 & Ph & 54 & 37 \\
\hline 4 & $\Phi . C_{. \beta n}$ & 31 & 10 \\
\hline 5 & A.R., & 23 & 5 \\
\hline 6 & n & 112 & 0 \\
\hline 7 & $3 / \mathrm{h} / \mathrm{n} / \mathrm{h} / \mathrm{h}+.0 \mathrm{q}$ & 58 & 50 \\
\hline 8 & $\lambda, \phi 中, \Phi \cap, \tau:$ & 18 & 27 \\
\hline 9 & he, h hTaq & 26 & 11 \\
\hline 10 & r.nn. & +2 & 18 \\
\hline \multirow[t]{2}{*}{11} & Phtoq & 57 & 0 \\
\hline & กไın,中ne & 480 & 224 \\
\hline
\end{tabular}

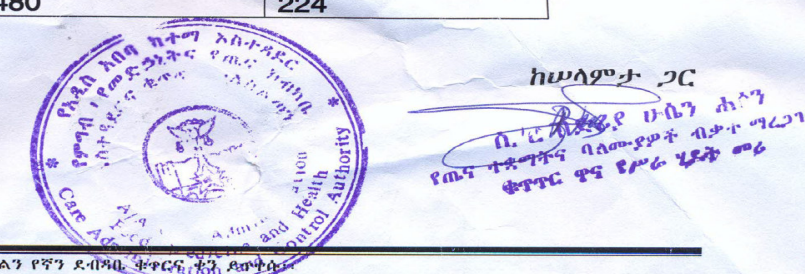

